\title{
Social transformation, development and globalization
}

\author{
Habibul H Khondker Zayed University, UAE \\ Ulrike Schuerkens École des Hautes Études en Sciences Sociales, France
}

\begin{abstract}
This article presents the various theoretical approaches to the study of social transformation and sociology of development since the emergence of this sub-field in sociology. In discussing various paradigms of social change and social transformation, the article questions the Eurocentric assumptions of a seemingly linear trajectory. In summarizing the developments in the field of sociology of development, this article synthesizes various theoretical strands such as modernization theories, dependency and worldsystems theories, and globalization and multiple modernity theories.
\end{abstract}

keywords globalization $\diamond$ global South $\diamond$ glocalization $\downarrow$ social change $\downarrow$ sociology of development

\section{Introduction}

Social transformation implies a fundamental change in society, which can be contrasted with social change viewed as gradual or incremental changes over a period of time. Social change has been the subject of a good part of sociology from Ibn Khaldun of the fourteenth century to Immanuel Wallerstein in the twenty-first century. Sociology of development is a field of study in sociology that primarily deals with issues of development and change in what is euphemistically called the global South, or in the past as developing countries. Studies of social transformation encompass a wide range of institutional and cultural changes in society throughout history. The modalities, causes and consequences of social change have been contemplated by philosophers and sages from time immemorial. The observation of Heraclitus (c. $535 \mathrm{BC}-475 \mathrm{BC}$ ) that 'you cannot step twice into the same river' captures the essence of the constancy of change. Change is eternal. Although the idea of social change is more or less universal, sometimes there are disagreements on the directionality of change as with the mechanisms of change.
In the Judeo-Christian-Islamic (sometimes, referred to as the 'western') discourse emanating from the ancient Egyptian and Greek civilizations, time was perceived as an arrow, moving forward in a linear trajectory. In the Hindu (Indian) concept, time was cyclical. The epochs, in the Hindu tradition, regress from the age of truth (satya yuga) to one of materialism, sin and corruption (kali yuga). The idea of millenarianism - an epochal change for the good after immersing in sin - is shared in a variety of religions. These cosmological differences account for the cultural variations in the perceptions of social transformation. In both Confucian and Hindu traditions, change was viewed with trepidation. Vestiges of such long-standing traditions are gradually giving way to the forces of modernization and global transformation. Karl Marx in the nineteenth century was prescient in predicting that the forces of modern capitalism would demolish the Chinese walls. Marx was heir to the western Enlightenment thought that made progress a cornerstone.

Sociopedia.isa

(C) 2014 The Author(s)

(C) 2014 ISA (Editorial Arrangement of Sociopedia.isa)

Habibul H Khondker and Ulrike Schuerkens, 2014, 'Social transformation, development and globalization', Sociopedia.isa, DOI: 10.1177/205684601423 


\section{Progress and classical sociology}

The notion of progress - the continuous unfolding of improvement in society - was embedded in Greek philosophy, which influenced the Enlightenment philosophy. An alternative enlightenment took place earlier in the Islamic world between 800 and 1200 (Starr, 2013) which did not endure. Sociology as a discipline was born in the context of the discourse over social progress when European society was exposed to changes induced by industrialization of the nineteenth century. In the writings of SaintSimon (1760-1825), August Comte (1798-1857), Herbert Spencer (1820-1903), Alexis de Tocqueville (1805-1859) and Karl Marx (1818-1883), the founding figures of sociology, social change or social dynamics occupied a central place. Max Weber (1864-1920) and Émile Durkheim (1858-1917) focused a great deal of attention on social change and its consequences, albeit from different theoretical emphases. The two dominant views on social change are rooted in the difference between social evolution and historical social change. For social evolutionists, social change follows a predictable and irreversible pattern. Society evolves from a simple to a higher, complex stage. This simple-minded view of linearity has now been replaced by non-linearity and contingency. Historians of social transformation, though not always free from the influence of evolutionism, examined social change as a process fraught with random and unpredictable events. The urban revolution of the Neolithic period (c. 1500 years BC) and the industrial revolution of the late eighteenth century were transformative (Goody, 1998).

Social revolutions - though with hind-sight look plausible - often come as surprises. The collapse of the 'really existing' Soviet socialism was but a recent case in the closing years of the twentieth century. The end of the socialist system also damaged the career of the orthodox Marxist perspective of social change. Yet academic Marxist or politico-economic scholarship on macro-historical social change continued to play an important role in the studies of social change (Hobsbawm, 1975; Moore, 1966; Skocpol, 1979; Tilly, 1990; Wallerstein, 1974). Weber's hermeneutical and comparative historical interpretations also introduced a rigorous study of social transformations which emphasized the role of culture. The works of David Landes (1983, 1998) and anthropological and ethnological research have provided considerable evidence and arguments in favour of taking culture seriously.

In developing the theories of social change and modernization, sociologists (and social scientists in general) draw upon the contributions of classical sociologists such as the works of those who were grappling with the rise of the capitalist industrial society in the nineteenth century. Their focus was on different aspects of this social transformation. While Marx was preoccupied with the new social relations of exploitation, and predicting a path towards an end of exploitation, Weber was concerned with the paradoxical consequences of modernization and cultural transformations, and de Tocqueville was examining the social circumstances that gave rise to the democratic social order. Durkheim, the first systematic sociologist, examined the social and cultural consequences of the growing division of labour and specialization in society brought in by industrialization. The major intellectual figures of the mid-nineteenth and early twentieth centuries were engaged with key aspects of modernity and the understanding of modern society which became a main concern of sociology. The master trends of modernization were: a move towards equality (equalization), administrative centralization (the emergence of state or state-like organizations), industrialization, urbanization and the rise of 'rationalized bureaucracy' (Weber). For the purpose of contemporary discussions on development (and modernization), one can see in this outlines of notions such as democratization, gender empowerment and issues of governance that rely on state capacity as well as rationalization and that have both a cultural dimension as well as an individual one.

\section{Rise of modernization theories}

In the post-Second World War period, sociologists turned their focus away from the 'really existing' social transformations and indulged in abstract theory building (Parsons, 1959). In the sociological formulations of Talcott Parsons who developed the theory of structural-functionalism, modernization was viewed as adaptation of the social system along the western model of social institutions. As a number of social scientists examined the social consequences of economic development (Moore, 1965; Smelser, 1959), others sought to explore the cultural and social institutional forces that thwarted development (Hoselitz, 1952). By then sociology embraced empiricism as a dominant methodological approach based on a positivistic epistemology.

Since the 1960s, the phenomenon of social change in the countries of the South has been a particular discussion topic of social scientists. A great variety of approaches can be found. These approaches began in the 1960s with the theories of modernization of Anglo-Saxon origin. During the same period, theories of structural change and a structural-functionalist approach were developed. 
Studies of social change in the twentieth century addressed such issues as social revolutions, the two World Wars, decline of imperialism, rise of the new nation-states, socialism, the Cold War and the collapse of the 'really existing' socialism. The postSecond World War period has been particularly fertile for the research and reflections on social change in the so-called Third World or what is now known as the global South.

\section{Modernization of the global South}

Both the temporal and structural aspects of development in the Southern countries were studied by modernization theorists. Colonization had an important influence on the structural changes of the local social systems, which had contacts with different colonial powers since the end of the nineteenth century in Asia and Africa and two centuries earlier in Latin America. Change induced by various colonial politics consisted of introducing a formal educational system, paid labour and a bureaucratic system (Schuerkens, 2001a). Despite great differences between local autochthonous groups, we can today find elites who support a rather identical development in their respective countries. Although colonial interventions came from outside the different regions, changes of the local autochthonous societies - that could have been separated by artificial colonial frontiers that were maintained after independence had to be adapted to this model originating from another social system that had had an increasing influence since the beginning of the twentieth century (regarding Africa south of the Sahara, see Schuerkens, 2001b).

The integration of different elements from this system with those of local societies happened slowly and gradually. Today, no groups remain worldwide which are not influenced by structures of global, and often western models thanks to international migrants, the Internet and mass media. The sort of change that occurred was dependent on the different local systems and their particular social structures. These societies resisted in different ways and/or changed important aspects of their social systems necessary for their survival because of the growing influence of the predominant model of development. At the same time, these local societies let very different cultural models coexist inside their particular societies (i.e. the important cultural differences between Africa and Asia); models that maintained and maintain ambivalent links with social structures imposed from outside their societies that later on scientists analyzed as situations characterized by glocal elements (Schuerkens, 2004).
At this point, the element time becomes an instrument for the analysis of changes that took place in these societies (Scott, 2011). The transformation of a social system never concerns all elements at the same time: several elements change in the initial phase, and force other elements to change until the emergence of another structural model can be observed (Schuerkens, 2001a, 2001b). Often, we can find a social structure that seems to be characteristic of the development of the societies of the South. Since the 1940s, in particular Africa south of the Sahara has been living this structural change with more or less intensity according to social systems or groups. Thus, the problem of social change is linked to an analysis that concerns the interaction of two rather different cultural, political and economic systems since the beginning of the twentieth century in Asia and Africa or even two centuries earlier in Latin America with colonial powers such as France, Britain, Spain and Portugal; and, at the same time, the factor time allows the explanation of numerous phenomena resulting from this interaction (Scott, 2011).

Such an approach requires the utilization of other research methods. In order to illustrate the disharmonies and frictions within Southern societies, it seems important to consider elements that result from the interaction of these societies with societies belonging to the global North. If we maintain that the interaction of Southern societies with societies of global, and often western culture led to the emergence of a new type of social system, despite the strong influences of former colonial powers, we are constrained to analyse this development by observing relevant development policies and the change of local autochthonous societies.

\section{The colonial modernization}

It makes sense to examine the sort of interaction that took place between individuals, groups and societal structures in a process of structural change. In this case, individual life stories can be considered to be the expression of a conflict between two structures (Schuerkens, 2001b). During the interaction that took place for instance in the colonial period, two different social systems confronted one another, but not on equal terms. The forces of coercion subdued and colonized the 'natives'. Parts of the social systems of the dominant power became universal values (formal education, bureaucracy, a paid salary, etc.) that large parts of the colonized had to accept and did accept.

During the analysis of transformation processes of societies and, in particular, processes linked to 
colonization, this phenomenon can be observed in an astonishing way. Colonization - considered as a gradual process of change, and as the development project of a powerful group (e.g. for France and Great Britain in the former German Togo: Schuerkens, 2001a) - brought about, in a rather short period of time, a fundamental restructuration of the social systems of African, Asian and Latin American societies. In particular, French colonization can be considered as an example of such processes of transformation, whereas Great Britain tried to respect parts of local social cultures in its colonies. The systematic introduction of an economic, political, social and cultural system different from those of the African societies implied that the colonial powers succeeded in introducing parts of their structures and in reaching their objectives.

An analysis of social change that took place inside the Southern groups has to consider the influence of the global western culture in a broad sense on these social systems, and the phenomenon of social change resulting from the interaction between them. This analysis is rather complex and surpasses theories of modernization, which privileged a development in the direction of the western model without considering particular elements of a given society. Furthermore, it surpasses dependency theories, which tried to explain this change by the external influence of an uneven economic world system. Only an analysis that takes into account these three dimensions will show the social relations and the particular character of change during the colonial period and its effects on actual processes of change (Balandier, 1988).

In general, social scientists using this approach consider reasons, forms and possible directions of social change. They reflect on the interest of society's members to assemble knowledge about past, present and future by taking into consideration the fact that it is nearly impossible to explain history completely or to make more than general predictions of future events (Scott, 2011).

\section{Transformation of social structure}

Change can be found and analysed in rather limited groups, in processes of transformation, which are of varying lengths and of varying character, and, if the factor time is considered, as short- or long-term change or as continuous or non-continuous change. The sociological explanation of change is related to the structure that changes and to elements that cause this change. The analysis of social change tries to show conditions and factors that cause the movement of a society from one particular situation to another (see Schuerkens, 2001b).

Two problems can be found here. On the one hand, elements must be established which are at the origins of change, and, on the other, original and final situations of transformation processes must be characterized. To tackle transformations means that the sociologist or the social anthropologist has to consider all aspects of a social system that form a given structure, the mechanisms of selection for different actions and the possibility of resulting actions.

Processes may be represented by unique structural characteristics that structure a sequence of events. A social process can only be explained and characterized by the isolation of significant elements that form a given structure, and by an analysis of their relations. A particular moment of a transformation process can be demonstrated by linking several elements and their mutual relations. The change of a given structure or the appearance of two different structures represents various periods of social history. Without the concept of structure, social processes and history in its particular aspect of development cannot be understood.

The approach of Teune and Mlinar (1978) tried to include these aspects in a theory of social change. This conceptual model can be considered as a heuristic framework. Both scholars underline that they present a theory that takes into consideration societies of the South and the North, their past, their present and their future. According to them, development is a characteristic element of all social systems. It is defined by a growing diversity of systemic components, and a further integration of these or other components. Social development takes place between the poles of diversity and integration: the extreme point of integration means that the stability of different components of a system is so high that a continuous development, because of the rigidity of the structure, is no longer possible. The development of a system depends on the interaction between diversity and integration, which indicates the particular situation of the social system.

According to the authors, integration is the degree of probability of a change of characteristics of a specific system, which is caused by the change of its elements (Teune and Mlinar, 1978: 43). Diversity as a structural particularity of a system can be deduced from the distribution of the characteristics of a system's elements (Teune and Mlinar, 1978: 35). Thus, social development is a process that links the levels of integration and diversity (Teune and Mlinar, 1978: 44). The growth of these levels means the direction of social development. However, possibilities of disintegration or stagnancy are not excluded.

According to the authors, the transformation of a system happens at the moment when the system has 
attained its limits of diversity and integration. Then, a new principle of integration of a society appears, which, at the same time, represents a transformation of the system and its characteristic structures. Furthermore, the degree of development depends on the quantity of system elements, which means that a higher variability of system elements permits a larger systemic change. This process can be imagined in the following way: at a particular instant, a new element is introduced; this element raises the diversity of the system, but reduces its level of integration; different components of the system accept the new element.

The probability that a new element is produced accrues. The process that we describe here begins a new cycle with the creation of another element (Teune and Mlinar, 1978: 72). Therefore, each new element reduces the degree of system integration and raises, at the same time, the total number of its elements (diversity). The new element has to be integrated in the system. During this movement, it changes the links between the different elements. The degree of integration rises according to the degree of development of the system (Teune and Mlinar, 1978: 74ff.). When we return to the conceptual scheme of transformations, we find that the development that took place during the colonial period in Asia, Africa and Latin America was often conceived by making use of evolutionary ideas. The approach of France is interesting insofar as this country pursued a development according to a particular model, the French one. It is evident that this sort of development led in the decades of French colonization to frictions, breakups and anomic situations. Fifty years after the rapid decolonization of most of the countries of Africa south of the Sahara, it is agreed that this development followed a global and even western pattern (Godelier, 1995: 169, 175), without the disappearance of certain cultural elements of African groups. The problem which has now to be tackled is the urgent duty to describe this sort of development, which was conceived and practised by countries such as France, Great Britain, Portugal and Spain, and its unforeseeable effects, which were caused by elements of the cultures of the local groups interacting with western models. Today, the question is no longer to find possible ways of development, but actual tendencies must be emphasized, and secondary effects must be analysed.

\section{Critique of modernization theories}

Some of the main problems of the post-Second World War sociological studies of modernization were - as critics pointed out later - that they were on the one hand abstract and ahistorical and on the other hand ethnocentric and used the West as the referent against which they measured the non-western societies. No theory has come under heavier attack than the Eurocentric modernization theory, which was steeped in the ideology of progress. Modernization was seen as replacement of so-called traditional institutions and practices by those of the modern West. The rest of the world, considered 'underdeveloped' would develop - it was thought if it followed the western model. Writers such as André Gunder Frank (1966), Samir Amin (1974), Fernando Cardoso (1977), Fernando Cardoso and Enzo Faletto (1979) and J Samuel Valenzuela and Arturo Valenzuela (1978) strongly criticized such unilinear and ethnocentric modernization theories.

In the 1970 s, as a result of such critiques, modernization theories as such fell into disrepute. Sociologists moved to analyse new problems, formulating dependency theory and the world-systems theory of Immanuel Wallerstein (1974) and providing detailed historical accounts of development and underdevelopment. The main contribution of this strand of studies was to bring historical studies on development back to centre stage. Drawing upon the Marxist-inspired historical debates over the transition from feudalism to capitalism, studies on colonial endeavours and empirical studies on the developing world produced a rich literature. Important historical works on development such as Karl Polanyi's The Great Transformation (1944) or Paul Bairoch's The Economic Development of the Third World since 1900 (1975) provided a comprehensive view of social change. Alexander Gerschenkron's classic study Economic Backwardness in Historical Perspective: A Book of Essays (1962) focused on late-starters of industrializing Europe. Using industrialization as the hallmark of economic progress, Gerschenkron examined the role of states in creating institutions (such as banks) and ideologies (i.e. ideas, dispositions, cultural values) as motors of economic growth. Socio-economist writing such as Gunnar Myrdal's Asian Drama (1968) in three volumes opened up new horizons in comparative development studies which placed a good deal of attention on culture and social values as impediments to economic growth.

As some historically minded sociologists of modernization turned their attention to various social trends at a macro level, there were others who sought to examine changes at the micro, individual level. The work of Alex Inkeles is representative of this new development. Inkeles and his associates embarked on a cross-national study of individual modernity in the mid-1960s for which they collected data from six countries. With the help of social psychologists, Inkeles developed an individual 
modernity scale, known as the overall modernity index (OMI), which later attracted a fair amount of criticism.

\section{Neo- and multiple modernities}

In the closing years of the twentieth century and the first decade of the present century, while some sociologists were lured by theories such as post-modernity in the wake of the collapse of socialist systems, theories such as neo-modernization and multiple modernities (Eisenstadt, 2006) or alternative modernities emerged. Eisenstadt's approach of multiple modernities obtained some influence among sociologists. According to this paradigm, development options are understood not as a failure or a lack of a general model, but as a singular manifestation of modernity. The observed variations are considered by this approach as typical of an overarching framework of modernity. The research of these theorists assumes that one can determine a common core of societies that can characterize a modern, singular society and different historical heritages in different regions, mainly related to major religions (Christianity, Hinduism, etc.). Eisenstadt (2006) claimed that there was more than one modern variety, because the core of modernism was not content fixed, but reacted dynamically.

This cultural-historical approach is not, however, considered by its critics as sufficient for diverse reasons (e.g. Schmidt, 2006), and though the newer variant of research on capitalisms, democracies, or cultural systems goes in the right direction, an overall, synthesizing macro-sociological perspective is still lacking, as had been submitted by research on modernization. It is now assumed that there will be no convergence of countries and regions towards a single modern pattern or that this has ever been the case, since not the same institutional solutions are or were found.

These developments in sociological theories answered some of the charges of ethnocentrism of the earlier modernization theories as the new frameworks allowed for examining societies that pursued modernity on their own terms, in view of their cultural and social specificities. Inglehart and Baker (2000) provided a re-evaluation of modernization theories and defended a return of this framework in a modified form. The earlier model of modernization was one of a singular model that fits all. The new approaches motivated by the rise of Japan and other modern societies that followed a different trajectory, gave impetus to sociological theorizations. The emergence of Japan as well as other East Asian societies and their successful economic systems not only provided impetus to the rise of the idea of alternative modernity, it also brought to the fore the issue of culture and social values in explaining economic development. These developments also created possibilities to empirically examine the propositions of alternative modernities. It is worthwhile to look at the propositions of multiple modernities as well as a number of empirical surveys such as PEW surveys and international Gallup surveys where various social trends are monitored. Here the World Values Survey of Ronald Inglehart of the University of Michigan is worth mentioning (World Values Survey of 2005). Such cross-cultural surveys shed valuable light but they are no substitutes for more in-depth localized studies that combine both survey methods as well as qualitative studies.

The concept of path dependence, which has been emphasized in recent years by various scientists and researchers (Beyer, 2005; Goldstone, 1998; Mahoney, 2000) directed attention to contingent histories and questions of development. This argument is based primarily on the unilinear evolutionism of Parsons. Shalini Randeria (1999, 2000) has further developed Eisenstadt's model and speaks of 'entangled modernities' or woven forms. She proposes to abandon the idea of parallel evolving manifestations of modernity and instead speaks of a model of interwoven forms that has arisen in the course of world history. Today, institutional similarities can be found in various countries which are the results of imitation, mutual learning and acquisitions.

One can assume that forms of institutions and organizations can be transferred more easily than individual cultural or philosophical aspects. Modernity is thus, according to Shalini Randeria, a global arena that constantly looks for exchange, but this should not necessarily lead to convergent developments. Meanwhile, a variety of studies shows that the forms of western modernity cannot be copied or have ever been copied, but they have been connected with local forms to produce new glocal units, and often have a specific character, whose structure and function may be similar across regions and countries. For example, Hall and Soskice (2001: 60) have demonstrated that the variants of capitalist development do not claim against world economic development, but develop in and with it. However, it should be noted that these global processes remain in their various social dimensions still under-analysed.

\section{Globalization and glocalization}

Broadening the scope of modernization and development studies, theories of globalization emerged in the last two decades of the twentieth century 
(Nederveen Pieterse, 2006, 2012; Robertson, 1992; Robertson and Khondker, 1998; Therborn, 2000; Turner and Khondker, 2010). Globalization meant an intensification of global processes and structures. Themes of connectivity, diversity and unevenness addressed in the multiple modernization and the world-systems theories were incorporated into the globalization theories (Lechner and Boli, 2000, 2004). At least four strands of globalization theories shape the discussion of social transformation in the first decade of the twenty-first century: globalization as a transhistorical process (Robertson, 1992; Therborn, 2000), as global modernization (Giddens, 1994), as critical discourse of neoliberal globalization (Appelbaum and Robinson, 2005; Stiglitz, 2002) and as glocalization (Robertson, 1995). According to the dictionary meaning, the term 'glocal' and the process noun 'glocalization' are 'formed by telescoping global and local to make a blend' (The Oxford Dictionary of New Words, 1991: 134 quoted in Robertson, 1995: 28). The term was modelled on the Japanese word dochakuka, which originally meant adapting farming techniques to one's own local condition. In the business world, the idea was adopted to refer to global localization. The word as well as the idea came from Japan (Robertson, 1995: 28). According to Wordspy, glocalization means 'the creation of products or services intended for the global market, but customized to suit the local cultures' (www.wordspy.com/words/). Although the term glocalization has come into frequent use since the late 1980s, there were several cognate terms that social scientists used and continue to use. One such related word, which has been in use in the social sciences and related fields for quite some time, is indigenization.

Some social scientists claimed that social sciences such as sociology and political science, even psychology, were products of western social experiences, therefore when these fields of enquiry were transported and transplanted to non-European or nonwestern contexts such as Latin America, Asia, or Africa there was a need for indigenization of these subjects. The idea of indigenization has created quite a bit of controversy among social scientists because it raises fundamental questions about the generalizability of social scientific ideas and concepts. However, we suggest that indigenization can be seen as similar to localization. In both concepts, there is an assumption of an original or authentic 'locality', or 'indigenous system' - an assumption that may not withstand critical scrutiny.

One of the consequences of globalization is that it opens up doubts about the originality and authenticity of cultures. If one takes a long-term view of globalization, 'locality' or 'local' itself is a conse- quence of globalization. Today, there are hardly any longer sites or cultures in the sense of societies that can be seen as isolated or unconnected from global, transnational processes.

Robertson, one of the pioneers in the study of globalization, did not view globalization as a recent phenomenon nor did he see it as a consequence of modernization. The theories of modernization came under serious attack in sociology because of such assumptions as unilinearity and convergence. As our knowledge of the world increased, many writers pointed out that those cultural differences are not all that superficial, and non-linearity and multi-linearity are better descriptions of global modernity. Social sciences in order to claim scientific status cannot afford to forfeit their claim to universality and universal knowledge. However, social sciences must be context sensitive but not context dependent. It is in this sense that Robertson conceptualized globalization in the twentieth century as "the interpenetration of the universalization of particularization and the particularization of universalism' (Robertson, 1992: 100, emphasis in the original). Building on Robertson's framework, Khondker (2004) argued that globalization or/and glocalization should be seen as an interdependent process. The problem of simultaneous globalization of the local and the localization of globality can be expressed as the twin processes of macro-localization and micro-globalization.

Macro-localization involves expanding the boundaries of locality as well as making some local ideas, practices and institutions global. The rise of worldwide religious or ethnic revivalist movements can be seen as examples of macro-localization. Micro-globalization involves incorporating certain global processes into the local setting. Consider social movements such as the feminist movements or ecological movements or consider new production techniques or marketing strategies, which emerge in certain local contexts. Over a period, these practices spread far beyond that locality into a larger spatial and historical arena. Or, consider the print industry or computer industry: a specific location of its emergence has now become a global phenomenon. Overcoming space is thus globalization in a certain sense. In this view of globalization, globalization is at the same time glocalization. This view is somewhat different from the way Giddens conceptualizes the relationship between the global and the local. Globalization, for Giddens, 'is the reason for the revival of local cultural identities in different parts of the world' (Giddens, 2000: 31). While in this view the local is the provider of the response to the forces that are global, we argue that the local itself is constituted globally.

The main propositions of glocalization are not 
too different from the main arguments of a nuanced version of globalization. (1) Diversity is the essence of social life; (2) globalization does not erase all local differences even in the long run; (3) autonomy of history and culture gives a sense of uniqueness to the experiences of groups of people whether we define them as cultures, societies, or nations; (4) glocalization and the research results linked to this strand remove the fear from many that globalization is like a tidal wave erasing all differences and flattening the world. Nevertheless, there are still a number of popular books (Friedman, 2005) and articles on the subject of globalization that give the impression that it is a force that creates a uniform world, a world where barriers disappear and cultures become amalgamated into a global whole.

As we have entered the third millennium, many of the age-old problems of differences of cultures and religion remain. Glocalization promises a more historically grounded understanding of the complex, interconnected, uneven world.

\section{Globalization is not westernization}

Some writers view globalization as the worldwide spread of 'westernization'. This view is either erroneous or contains only partial truth. From a superficial point of view, various processes outwardly seem that the world is, indeed, becoming westernized. One can look to the popularity of western music, movies and 'McDonald's' as examples of westernization. More and more countries play the top hits of the US pop chart, and Hollywood movies and USmade television serials became ubiquitous to the extent that some writers use the term 'Americanization' to describe these processes of cultural transmission. This notion originally reflected continental European reactions to American-style mass consumption.

However, a closer look will reveal that these cultural goods have different meanings in different societal and cultural contexts with uneven impact on classes and age groups. Some rare products are consumed without any modification, most are modified and indigenized to suit the local contexts of understanding, and there are exceptional situations where the intentions are completely inverted. For example, McDonald's adapts its food to local eating habits such as in India or China; popular cultural products have been deterritorialized and gain meanings in the local contexts that are varied.

In the past, many writers found it necessary to distinguish modernization from westernization. Modernization was believed to be a set of cultural practices and social institutional features that histor- ically evolved in Europe and North America, commonly referred to as the West. The need to separate westernization from modernization was motivated more by nationalism than pure intellectual reasons, because historically speaking, most of the modern cultural traits began in the West, a historical fact that was difficult to accommodate in a nationalistic political culture. The western scholars in the nineteenth century were also guilty of making exaggerated claims of western superiority. Max Weber, a German sociologist, was correct to claim that western rationality and science had become a universal characteristic element of modernity. Many Indian sociologists took pains to delineate the differences between modernization and westernization. Similar discussions exist with regard to so-called westernization of the Ottoman Empire, the modernization of Japan since the Meiji restoration of 1868 , or the modernization of China in the early part of the twentieth century such as the May 4th Movement of 1919. In these late modernization processes, many societies were borrowing ideas, knowledge and technology, most of which were generated in the early modernized societies in Western Europe. However, the geography of the West kept shifting. In the nineteenth century, when Germany was modernizing, the idea of the West was limited to Western Europe (mainly Britain and France). In some post-colonial situations, the demarcation was based more on political expedience (former colonies in Asia and Africa) than logical or intellectual merit. The distancing from westernization can also be understood as a reaction to centuries of domination and exploitation of the former colonies by the western (mainly European) powers. However, over time a more objective consideration of history indicates that many of the traits that spread worldwide originated in certain geographical regions. Yet as these traits were transplanted elsewhere, they became mutated and assumed different forms in various contexts. For example, the roots of representative democracy in England go back to the Magna Carta of 1215. However, as Westminsterstyle parliamentary democracy was institutionalized in India, Malaysia and other former British colonies, it mutated in light of the local social and cultural milieu.

Westernization as a term is not equivalent to globalization. Nevertheless, westernization can be seen as an aspect of globalization. Certain institutional features and cultural traits that originated in the West were put in place in many other geographical regions, lock, stock and barrel, under the framework of global interconnections and diffusion or forced implantation under colonialism. Yet over time, these institutions and practices mutated and assumed new meanings. Therefore, westernization 
can be seen as the beginning of the process. The cultural features, borrowed or imitated themselves, mutated in the source countries as well. Thus, westernization as a category has limited conceptual value. One can associate certain literary forms, genres and traits as part of the cultural zone we vaguely call 'the West', yet these are mere influences as one can see in artistic, literary and architectural styles.

\section{Convergence or divergence?}

Writers such as John Meyer have used the idea of isomorphism (a term borrowed from botany), which means replication of the same form yet separated from the main source. His research has shown that modern education - not western education, though it was perhaps modified and institutionalized in the West - has spread worldwide and a similar set of values and practices have emerged in diverse settings in globalized universities unified by a common focus on rationality and empirical studies. Some institutions are increasingly becoming glocalized around the world, as people try to cope with problems and challenges from financial to ecological crises.

We have shown here that one can no longer speak of a change of institutions in the direction of a global pattern. Instead, one can find transnational processes that should be examined more closely in globalization studies in order to demonstrate transnational connections of individuals, organizations, companies, or countries that have increased in the last decades. States have, for example, expanded their ability to control people through transnational spaces (Interpol). They have supported interactions, ideologies and institutions; the hierarchies of gender, ethnicity and class within nations have expanded across states. Transnational spaces, which are composed of real and virtual social spaces, exist across nation-states. Individuals, groups and organizations also expand beyond these areas (Boccagni, 2012).

Today, one cannot deny that empirical findings on individual measurable indicators such as GDP, life expectancy and literacy rate suggest convergence, as Schmidt (2007) has emphasized. Yet, these figures hide similar but different institutions and systems, and show qualitative differences that cannot be overlooked. One can for example point to the various forms of capitalism in Western Europe, Japan and China, which indicate that cultural factors receive their own specific expression (e.g. in the dimension of individualism/collectivism or under ethical concepts). One may also refer to social globalization, measurable through personal contacts (tourism, telephone traffic, residing abroad) and information flows (Internet users, the number of television stations, the number of newspapers); cultural similarities, such as the number of McDonald's restaurants, Ikea shops and the book trade (Dreher, 2006; Dreher et al., 2008), can be found. One might think that these measurements are threatening the cultures of the South. But are we measuring social aspects of globalization? It seems instead as if transnational networks of people living as migrants in other regions are being described here.

\section{Development trends in the twenty-first century}

Since the collapse of the socialist system, the optimism of capitalist consolidation and a neoliberal consensus has come under serious doubt. The financial crises of 1997-8, known as Asian crisis, and 2008-9, which has been labelled as the worst global financial crisis since the 1930s, have had significant consequences on global development and on socioeconomic transformations in numerous societies of the South and the North. The crises were the reminder of the financial interdependencies of the countries in the world. In 2011-12, the emergent countries had to cope with feeble demand in the highly developed countries and the volatile character of international finances. Global economic weakness and defiant attitudes of international investors let emerge structural constraints in development tendencies in India and China with decreasing economic growth and increasing middle classes. Countries strongly linked to the euro region have been very concerned with the financial crisis and high unemployment. Central and Eastern Europe have benefitted from the strong economic situation in Germany. The countries of North Africa have been influenced by the Arab Spring, which meant political turnovers but difficult economic situations for a region that has been closely linked to the euro zone in crisis. Africa south of the Sahara has seen high growth rates (4.9\% in 2011 including South Africa). Increasing commercial flows with China have given this region access to dynamic countries in the East, and less exposure to the situation in European countries. In China, exports reduced in 2012 compared to 2011 (from $24 \%$ to $7.6 \%$ ) (CEPII, 2012: 19), and economic growth decreased from $9.2 \%$ in 2011 to 8.1 $\%$ in the first three months of 2012 (CEPII, 2012: 19). Yet China has decided to focus on the development of its interior market where large middle classes aspire to consume more than in the past.

China's economic influence in Africa and Latin America is still growing and very important for the industry in these regions. Cheap industrial products from China are introduced in Southern countries 
and menace African and Latin American local products. As wages are higher in Latin America and parts of Africa south of the Sahara, manufactured products from these regions cannot compete with Chinese products on global markets. Local products from these regions are rarely sent to China but most often to other regions in the rest of the world. From 2000 to 2010 , one can find these changes in exports affecting Turkey, Brazil, India and South Africa. The competitive character of Chinese industry is an important challenge for the industrialization of countries in the South. Some economists have even suggested protecting the economies of African countries, for example, against Chinese products (Collier, 2008: 169)

At the beginning of 2000 , scholars thought that regions would try to build regional economic unions, such as the USA with Latin America, Europe with Africa, and Japan with some Asian countries. This development was not realized. Today, Africa is highly linked to China and other Asian countries. In the Maghreb region, China has become the principal supplier of Algeria, replacing France. Regional economic treaties have been developed in the last decade and contribute to economic positions in the global economy. In Asia and Africa, commerce is realized among South-South partners; in Latin America, commerce is often limited to the sub-region.

South-South exchanges may thus represent huge parts of the world economy in the coming years so that North-South links are affected and may decrease in relation to South-South links. So far, it seems there will be no separation from the South of the North due to the interdependencies of all global regions, but the sense of the North-South relation will change. The fact that the global economy is linked has meant that the global financial crises had various influences all over the world (see Schuerkens, 2012). The rise of China as an important global player has meant that there has been a change in the global world caused by a population that represents one-fifth of the world population - a far cry from the $3.5 \%$ which was the case for the USA compared to Great Britain at the end of the nineteenth century.

However, one also has to take into account the fact that in today's world when we look at the highincome countries and/or countries with a high HDI (Human Development Index), it is obvious that some of them are the countries where early modernization sprang up, or are regions where people from early modernizing nations of Europe resettled. Japan remains an historical exception that mobilized its state capacity to launch its own development and modernization in the late nineteenth century following the Meiji restoration. Other Asian countries that made it to the high-income and high HDI group were following the Japanese model to varying degrees (e.g. Singapore and South Korea). The other highincome economies in the Gulf States used their hydrocarbon resources (petroleum and gas) and generated wealth to transform their societies and to catch up with the modern world. In the opening decade of the twenty-first century, the rise of Brazil, Russia, China, India and South Africa (BRICS) presents another chapter in the history of modernization where highly populated countries have been able to attain economic growth and social development rivalling developed countries of the North.

In the closing years of the twentieth century, there has also been a shift of focus from growth oriented to well-being oriented approaches to development. Amartya Sen's influence cannot be denied in this realm. The capability approach advanced by Amartya Sen (1999) and Martha Nussbaum (2001) is human centred. Following a shift from comparative mega-projects to individual-focused studies, within the segmented and individual-focused capability approach, it is now widely accepted that enhancing women's capabilities - what is often viewed as gender empowerment - yields many benefits to societies. Women as a group have been identified as an important constituency in the discussion of social and cultural development spawning a subfield of study within development studies, titled 'Women in development' and 'Women for development' (McMichael, 2007). Thus, the well-being of women has been identified as a goal of development with multiplier beneficial effects for the individual household and society. The idea of microfinance has evolved through ground-level experiences in Bangladesh and elsewhere and is now recognized as a useful tool for uplifting poor women's socioeconomic situation.

\section{Conclusions}

The considerations above lead us to present a theory of connected yet differentiated modernization that can be further developed by cultural and structural comparisons to identify different constellations of institutions and their relationships. The importance of culture is weighted differently during the change of structures. So in today's global society, culture plays an important role that is responsible for different dynamics. Each of these can be characterized by certain types of societies of the North and the South, or within a society of various cultural milieus. In this sense, we think the multiple modernity approach to civilizations is too large, but some aspects of the glocalization debate with its different levels (countries, regions and local contexts) should be underlined in 
the debate on change and transformation. This would then lead to research that examines institutional complexes where culture plays a significant role.

Eisenstadt's approach is interesting in terms of collective identities of geographic regions, such as Latin America or sub-Saharan Africa, where different national societies have distinct identities characterized by common colonial political influences. These societies can hardly resist transnational forces that bring them together again, and the examples of economic unions such as Mercosur (Mercado Común del Sur) or CEDAO (Communauté économique des États de l'Afrique de l'Ouest) show this tendency. The recent cycles of globalization can thus only be understood as transnational flows, such as the Andean Community or ASEAN. These regions that combine various states in a group are characterized by transnational flows and a partly shared history.

Sanjay Subrahmanyam (1997, 2005) spoke in this regard of 'connected histories', while Michael Werner and Bénédicte Zimmermann (2002, 2006) coined the term 'histoire croisée'. This perspective makes it possible to take into account mutual influences and resistances, new combinations and transformations. These mutual interactions show a network of dynamic relationships, defined by certain connections from one to the other. A transnational perspective that exceeds migration processes is therefore to be welcomed in the study of transformations and development(s). Today, we realize more and more that international groupings and agreements come up like mushrooms out of the ground. The concepts of globalization and transnationalism define lines of research that exist in parallel. They introduce practices across borders, social networks that exist or have existed prior to the globalization of the last 30 years and that made possible a movement of ideas and people which can be analysed. Such a perspective allows us now to understand how the cultural history of macro-regions is connected, how it might affect collective identities, and characterize the social, political and cultural forces of a society.

\section{Annotated further reading}

McMichael P (2012) Development and Social Change: A Global Perspective. Pine Forge, CA: Sage.

A good overview of social change from an economic perspective of long-term historical change from development to globalization.

Schuerkens U (ed.) (2003) Global Forces and Local LifeWorlds: Social Transformations. London, Delhi and Thousand Oaks, CA: Sage.

The first chapter is an excellent introduction into research on globalization and localization in sociology and anthropology. How are global forces impacting on local lifestyles? Where does the personal stand in relation to globalization? Global Forces and Local Life-Worlds explores these questions using a mixture of sociological and anthropological analysis and case study methods. Demonstrating the tensions of retaining cultural integrity in the face of the levelling processes associated with modernity, this book locates the problems of globalization and localization in the appropriate anthropological and sociological dimensions; examines the relationship between culture and identity; and explores the varieties of modernity.

Turner B and Khondker HH (2010) Globalization East and West. London: Sage.

Do we confuse globalization for Americanization? What are the distinctive elements in the interplay of the local and the global? This much-needed book is the first full-length text to examine globalization from the perspective of both the West and the East. It considers globalization as a general social and economic process, and the challenges it presents for western social science. The meaning of a global perspective is explored through various concrete examples: religion, migration, medicine, terrorism, global disasters, citizenship, multiculturalism, media and popular culture. Introduced with a foreword from Roland Robertson, the book is brimming with novel interpretations and fresh insights that will contribute to illuminating the practical realities of globalization.

\section{References}

Alexander JC and Sztompka P (eds) (1990) Rethinking Progress, Movements, Forces, and Ideas at the End of the 20th Century. London and Boston, MA: Unwin Hyman.

Amin S (1974) Accumulation on a World Scale: A Critique of the Theories of Underdevelopment. New York: Monthly Review Press.

Appadurai A (1996) Modernity at Large: Cultural Dimensions of Globalization. Minneapolis: University of Minnesota Press.

Appelbaum R and Robinson WI (2005) Critical Globalization Studies. New York: Routledge.

Bairoch P (1975) The Economic Development of the Third World since 1900. London: Methuen.

Balandier G (1988) Le Désordre, éloge du mouvement. Paris: Fayard.

Berger PL and Huntington SP (eds) (2002) Many Globalizations: Cultural Diversity in the Contemporary World. Oxford: Oxford University Press.

Beyer J (2005) Pfadabhängigkeit ist nicht gleich Pfadabhängigkeit Wider den impliziten Konservatismus eines gängigen Konzepts. Zeitschrift für Soziologie 34(1): 5-21.

Boccagni P (2012) rethinking transnational studies: Transnational ties and the transnationalism of 
everyday life. Social Theory 15(1): 117-32.

Cardoso FH (1977) The Originality of the Copy: ECLA and the Idea of Development. Cambridge: Cambridge University Press, Centre for Latin American Studies.

Cardoso FH and Faletto E (1979) Dependency and Development in Latin America. Berkeley: University of California Press.

CEPII (2012) L'Économie mondiale 2013. Paris: La Découverte.

Collier P (2008) The Bottom Billion. Oxford: Oxford University Press.

Dreher A (2006) Does globalization affect growth? Evidence from a new index of globalization. Applied Economics 38(10): 1091-110.

Dreher A, Gaston N and Martens P (2008) Measuring Globalization: Gauging its Consequences. New York: Springer.

Eisenstadt SN (2006) Multiple Moderne im Zeitalter der Globalisierung. In: Schwinn T (ed.) Die Vielfalt und Einheit der Moderne. Kultur- und strukturvergleichende Analysen. Wiesbaden: VS Verlag für Sozialwissenschaften, pp. 37-62.

Frank AG (1966) Development of underdevelopment. Monthly Review 18: 17-30.

Friedman T (2005) The World is Flat. New York: Farrar, Strauss, and Giroux.

Gerschenkron A (1962) Economic Backwardness in Historical Perspective: A Book of Essays. Cambridge, MA: Belknap Press of Harvard University Press.

Giddens A (1994) Beyond Right and Left. Cambridge: Polity.

Giddens A (2000) Runaway World. New York: Routledge.

Godelier M (1995) L'anthropologie sociale est-elle indissolublement liée à l'Occident, sa terre natale? Revue Internationale des Sciences Sociales 47, 143(1): $165-83$.

Goldstone JA (1998) Initial conditions, general laws, path dependence, and explanation in historical sociology. American Journal of Sociology 104(3): 829-45.

Goody J (1998) Food and Love: A Cultural History of East and West. London: Verso.

Hall PA and Soskice D (eds) (2001) Varieties of Capitalism: The Institutional Foundations of Comparative Advantage. Oxford: Oxford University Press.

Hannerz U (1989) Culture between center and periphery: Towards a macroanthropology. Ethnos 54(3-4): 200-16.

Hobsbawm E (1975) The Age of Capital. London: Weidenfeld and Nicolson.

Hoselitz BF (1952) Non-economic barriers to economic development. Economic Development and Cultural Change 1(1): 8-21.

Inglehart R (2005) World Values Survey of 2005. Ann Arbor: Center for Social Research: University of Michigan.

Inglehart R and Baker WE (2000) Modernization, cultural change and the persistence of traditional values. American Sociological Review 65(1): 19-51.
Inkeles A and Smith DH (1966) Becoming Modern. Cambridge, MA: Harvard University Press.

Khondker HH (2004) Glocalization as globalization: Evolution of a sociological concept. Bangladesh eJournal of Sociology 1(2).

Landes D (1983) Revolution in Time: Clocks and the Making of the Modern World. Cambridge, MA: Harvard University Press.

Landes D (1998) The Wealth and Poverty of the Nations. Cambridge, MA: Harvard University Press.

Lechner F and Boli J $(2000,2004)$ The Globalization Reader, 1st and 2nd edns. Malden, MA: Blackwell.

McMichael P (2007) Development and Social Change: A Global Perspective, 4th edn. Los Angeles, London, New Delhi and Singapore: Pine Forge Press.

Mahoney J (2000) Path dependence in historical sociology. Theory and Society 29(4): 507-48.

Meyer JW (2005) Weltkultur. Wie die westlichen Prinzipien die Welt durchdringen. Frankfurt a.M.: Suhrkamp.

Moore WE (1965) The Impact of Industry. Englewood Cliffs, NJ: Prentice Hall.

Moore B (1966) The Social Origins of Dictatorship and Democracy. Boston: Beacon Press.

Myrdal G (1968) Asian Drama: An Inquiry into the Poverty of Nations, 3 vols. New York: Harper Brothers.

Nederveen Pieterse J (2006) Oriental globalization: Past and present. In: Delanty G (ed.) Europe and Asia Beyond East and West. London: Routledge, pp. 15-37.

Nederveen Pieterse J (2012) Periodizing globalization: Histories of globalization. New Global Studies 6(2) Article 1.

Nussbaum M (2001) Women and Human Development: The Capabilities Approach. New York: Cambridge University Press.

Parsons T (1959) Structure and Process in Modern Society. New York: Free Press.

Polanyi K (1944) The Great Transformation. New York: Rinehart.

Randeria S (1999) Geteilte Geschichte und verwobene Moderne. In: Rüsen J, Leitgeb H and Jegelka N (eds) Zukunftsentwürfe. Ideen für eine Kultur der Veränderung. Frankfurt a.M. and New York: Campus, pp. 87-96.

Randeria S (2000) Jenseits von Soziologie und soziokultureller Anthropologie. Zur Ortsbestimmung der nicht-westlichen Welt in einer zukünftigen Sozialtheorie. In: Beck U and Kieserling A (eds) Ortsbestimmungen der Soziologie. Wie die kommende Generation Gesellschaftswissenschaften betreiben wird. Baden-Baden: Nomos, pp. 41-50.

Ringmar E (2009 [2005]) The Mechanics of Modernity in Europe and East Asia: Institutional Origins of Social Change and Stagnation. London: Routledge.

Robertson R (1987) Globalization theory and civilizational analysis. Comparative Civilizations Review 17(1): 20-30.

Robertson R (1992) Globalization: Social Theory and Global Culture. London: Sage. 
Robertson R (1995) Glocalization: Time-space and homogeneity-heterogeneity. In: Featherstone M, Lash $S$ and Robertson R (eds) Global Modernities. London: Sage, pp. 25-44.

Robertson R and Khondker HH (1998) Discourses of globalization. International Sociology 13(1): 25-40.

Roniger L (2011) Connected histories, power and meaning: Transnational forces in the construction of collective identities. Journal of Classical Sociology 11(3): 251-68.

Schmidt VH (2006) Multiple modernities or varieties of modernity? Current Sociology 54(1): 77-97.

Schmidt VH (2007) One world, one modernity. In: Schmidt VH (ed.) Modernity at the Beginning of the 21st Century. Newcastle: Cambridge Scholars Publishing, pp. 205-28.

Schuerkens U (2001a) Du Togo allemand aux Togo et Ghana indépendants: Changement social sous régime colonial. Paris: L'Harmattan.

Schuerkens U (2001b) Transformationsprozesse in der Elfenbeinküste und in Ghana: Eine historischvergleichende Analyse des Verhältnisses von Lebensgeschichten und strukturellen Wandlungsprozessen. Münster: Lit.

Schuerkens U (ed.) (2003) Social transformations between global forces and local life-worlds. Special issue of Current Sociology 51(3/4).

Schuerkens U (ed.) (2004) Global Forces and Local Lifeworlds: Social Transformations. Monograph book series: Sage Studies in International Sociology. London, Thousand Oaks, CA and New Delhi: Sage.

Schuerkens U (ed.) (2005) Social transformations and transnational migrations. Special issue of Current Sociology 53(2/4).

Schuerkens U (ed.) (2007) Globalization and Transformations of Local Socio-economic Practices. London and New York: Routledge.

Schuerkens U (ed.) (2010) Globalization and Transformations of Social Inequality. London and New York: Routledge.

Schuerkens U (ed.) (2012) Socioeconomic Outcomes of the Global Financial Crisis: Theoretical Discussion and Empirical Case Studies. London and New York: Routledge.

Schulz M (ed.) (1997) Entwicklung: Theorie - Empirie Strategie. Festschrift für Volker Lühr. Münster: Lit.

Schwinn T (2005) Weltgesellschaft, multiple Moderne und die Herausforderungen für die soziologische
Theorie. Plädoyer für eine mittlere Abstraktionshöhe. In: Heintz B, Münch R and Tyrell H (eds) Weltgesellschaft. Theoretische Zugänge und empirische Problemlagen. Stuttgart: Lucius, pp. 205-22.

Schwinn T (ed.) (2006) Die Vielfalt und Einheit der Moderne. Kultur-und strukturvergleichende Analysen. Wiesbaden: VS Verlag für Sozialwisenschaften.

Scott J (2011) Conceptualizing the Social World: Principles of Social Analysis. Cambridge and New York: Cambridge University Press.

Sen A (1999) Development as Freedom. Oxford: Oxford University Press.

Skocpol T (1979) States and Social Revolutions. New York: Cambridge University Press.

Smelser N (1959) Social Change in the Industrial Revolution. Chicago: Chicago University Press.

Starr F (2013) Lost Enlightenment: Central Asia's Golden Age From the Arab Conquest to Tamerlane. Princeton, NJ: Princeton University Press.

Stiglitz J (2002) Globalization and its Discontents. New York: W.W. Norton.

Subrahmanyam S (1997) Connected histories: Notes towards a reconfiguration of early modern Eurasia. Modern Asian Studies 31(3): 735-62.

Subrahmanyam S (2005) Explorations in Connected History: From the Tagus to the Ganges. Oxford: Oxford University Press.

Teune H and Mlinar Z (1978) The Development Logic of Social Systems. Beverly Hills, CA and London: Sage.

Therborn G (2000) Globalization. International Sociology 15(2): 151-79.

Tilly C (1990) Coercion, Capital and European States, AD 900-1990. Oxford: Blackwell.

Turner B and Khondker HH (2010) Globalization East and West. London: Sage.

Valenzuela JS and Valenzuela A (1978) Modernization and dependency: Alternative perspectives in the study of Latin American underdevelopment. Comparative Politics 10(4): 535-57.

Wallerstein I (1974) The Modern World-Systems. New York: Academic Press.

Werner M and Zimmermann B (2002) Vergleich, Transfer, Verflechtung: Der Ansatz der Histoire croisée und die Herausforderung des Transnationalen. Geschichte und Gesellschaft 28: 607-36.

Werner M and Zimmermann B (2006) Beyond comparison: Histoire croisée and the challenge of reflexivity. History and Theory 45(1): 30-50.

Habibul Haque Khondker is professor at the Department of Humanities and Social Sciences at Zayed University, Abu Dhabi, UAE. He was educated at the University of Dhaka, Carleton University, Ottawa and the University of Pittsburgh and has taught at the National University of Singapore. [email: habib.khondker@gmail.com]

Ulrike Schuerkens is senior lecturer at the École des Hautes Études en Sciences Sociales, Paris, France. She holds PhDs in sociology, and social anthropology and ethnology. She received her Habilitation from the University Paris 5. Ulrike is the current president of ISA-RC 09 Social Transformations and Sociology of Development. [email: Ulrike.Schuerkens@ehess.fr] 
résumé Cet article présente les multiples approches théoriques des études sur les transformations sociales et la sociologie du développement depuis la création de cette subdiscipline de la sociologie. En discutant des paradigmes variés du changement social et des transformations sociales, l'article met en question les idées d'une trajectoire apparemment linéaire. En résumant les approches dans le domaine de la sociologie du développement, l'article synthétise plusieurs approches théoriques comme celles des théories de la modernisation, de la dépendance, du système-monde, de la mondialisation et des modernités multiples.

mots-clés changement social $\diamond$ glocalisation $\diamond$ mondialisation $\diamond$ sociologie du développement $\diamond$ sud mondial

resumen Este articulo presenta diferentes enfoques teóricos sobre el estudio de la transformación social y la sociología del desarrollo desde los inicios de esta área de la sociología. Abordando diversos paradigmas de cambio social y transformación social, el artículo se pregunta sobre las hipótesis Eurocéntricas de una trayectoria aparentemente lineal. Resumiendo los desarrollos en el campo de la sociología del desarrollo, este artículo sintetiza diversas corrientes teóricas como, teorías de la modernización, teorías de la dependencia y del sistema-mundo, y teorías de la globalización y de las modernidades múltiples.

palabras claves cambio social $\diamond$ globalización $\diamond$ glocalización $\diamond$ sociología del desarrollo $\diamond$ sur global 